\title{
The Effect of a Cyclooxygenase-2 Inhibitor on Proliferating Activity in Breast Cancer: First Results
}

\author{
Frederic Buxant ${ }^{\mathrm{a}} \quad$ Fabienne Devreker $^{\mathrm{a}} \quad$ Jean-Christophe Noël ${ }^{\mathrm{b}}$ \\ a Department of Obstetrics and Gynecology, \\ ${ }^{b}$ Department of Pathology, CUB Hospital Erasme, Brussels, Belgium
}

\section{Key Words}

Breast cancer - Cyclooxygenase-2 - Proliferation index . Non-steroidal anti-inflammatory drugs

\section{Summary}

Objective: Cyclooxygenase-2 (COX2) is an inducible enzyme that converts arachidonic acid to prostaglandins. It is involved in diverse processes, such as inflammation, carcinogenesis and apoptosis. We investigated the effect of a COX2 inhibitor on the proliferation index in breast cancer. Patients and Methods: 13 patients with breast cancer received $50 \mathrm{mg}$ of diclofenac 3 times daily for 15 days. COX2 and the proliferation index $\mathrm{Ki}-67$ were evaluated in the biopsies and tumors obtained after surgery. An immunohistochemical scoring system was used. Results: COX2 was expressed at intermediate or high levels in $61.5 \%$ of the breast tumors. Ki-67 activity was distributed in 2 categories and decreased by $1-8 \%$ between the 2 cell populations. However, this difference was not found to be significant. Conclusion: COX2 is expressed in breast cancer and plays a role in its genesis. More clinical trials are needed to evaluate the potential of COX2 inhibitors (specific or not) in the treatment and/or prevention of breast cancer.

\section{Introduction}

Breast cancer (BC) is a major public health concern. Only a modest impact on BC mortality has been achieved by improved screening techniques and surgical, radiation and sys-

\section{Schlüsselwörter}

Brustkrebs · Cyclooxygenase-2 - Proliferationsindex . Nichtsteroidale Antiphlogistika

\section{Zusammenfassung}

Ziel: Cyclooxygenase-2 (COX2) ist ein induzierbares Enzym, welches Arachidonsäure in Prostaglandine umwandelt. COX2 nimmt an einer Vielzahl von Prozessen teil, darunter Entzündung, Karzinogenese und Apoptose. Wir haben die Wirkung eines COX2-Inhibitors auf den Proliferationsindex von Brustkrebs untersucht. Patienten und Methoden: 13 Brustkrebs-Patientinnen wurden 15 Tage lang dreimal täglich mit $50 \mathrm{mg}$ Diclofenac behandelt. In Biopsien bzw. operativ entfernten Tumoren wurden sowohl COX2 als auch der Proliferationsindex Ki-67 bestimmt und mittels eines immunohistochemischen Punktesystems bewertet. Ergebnisse: COX2 zeigte mittlere bis hohe Expressionsraten in 61,5\% der Mammatumoren. Die Ki-67-Aktivität konnte in 2 Kategorien unterteilt werden. Zwischen den beiden Zellpopulationen wurde ein Aktivitätsabfall von 1-8\% beobachtet, welcher jedoch nicht als signifikant gewertet wurde. Schlussfolgerung: COX2 wird in Brustkrebszellen exprimiert und spielt eine Rolle in der Brustkrebsentstehung. Weitere klinische Studien sind nötig, um das Potential von COX2-Inhibitoren (sowohl spezifisch als auch unspezifisch) in der Behandlung und/oder Prävention von Brustkrebs zu evaluieren.

temic treatment. The cyclooxygenases 1 and 2 (COX1/COX2) are key enzymes of prostaglandin synthesis as they catalyze the conversion of arachidonic acid to prostaglandin E2. Prostaglandin increases aromatase expression and activation, and is the enzyme that produces estrogen from androgens.

\begin{tabular}{ll}
\hline KARGER & ( 2006 S. Karger GmbH, Freiburg \\
Fax +49 7614520714 & Accessible online at: \\
$\begin{array}{l}\text { E-mail Information@Karger.de } \\
\text { www.karger.com }\end{array}$ & www.karger.com/brc
\end{tabular}

Dr. Frederic Buxant

Department of Obstetrics and Gynecology

CUB Hospital Erasme

1070 Brussels

Tel. +322 555-3684, Fax - 6841

E-mail frederic.buxant@ulb.ac.be 
Table 1. Patient characteristics $(n=13)$ : pathological TNM classification, and COX2 and Ki-67 measured in the biopsy specimen (B) and in the tumors ( $\mathrm{T})$ after surgery (following diclofenac administration)

\begin{tabular}{llllll}
\hline Patient & TNM & COX2-B & COX2-T & Ki-67-B, \% & Ki-67-T, \% \\
\hline 1 & pT3N2a & + & + & 16 & 22 \\
2 & pT4N3 & + & + & 29 & 26 \\
3 & pT4N3 & ++ & ++ & 32 & 31 \\
4 & pT1bN0 & + & + & 12 & 10 \\
5 & pT1cN0 & +++ & +++ & 30 & 29 \\
6 & pT1bN0 & +++ & ++ & 36 & 28 \\
7 & pT1cN0 & +++ & +++ & 49 & 43 \\
8 & pT1bN0 & + & + & 33 & 39 \\
9 & pT2N2a & +++ & ++ & 29 & 26 \\
10 & pT2N3b & + & + & 6 & 9 \\
11 & pT1bN0 & ++ & ++ & 6 & 6 \\
12 & pT1cN0 & ++ & ++ & 27 & 29 \\
13 & pT1cN1mic ++ & ++ & 6 & 3.5 \\
\hline
\end{tabular}

COX1 is constitutively expressed in most tissues and has a protective role in the gastrointestinal tract. COX2 is expressed constitutively in the brain, kidney and some other nervous tissues, and is inducible in most tissues in response to inflammatory and hormonal signals [1-3]. The expression of COX2 is elevated in a variety of human cancers, and inhibition of COX2 suppresses tumor growth in several animal models of carcinogenesis [3]. Recent reports suggest that $\mathrm{COX} 2$ may be directly involved in mammary carcinogenesis, since expression of COX2 was sufficient for formation of breast tumors in transgenic mice [4].

Studies of the administration of non-steroidal anti-inflammatory drugs (NSAIDs) to arthritis patients have encountered lower than expected rates of colorectal cancer. Further studies have found high COX2 expression in these cancers and inhibition of COX2 by NSAIDs [1,2]. However, BC studies show conflicting data. Some do report a reduced BC incidence with NSAID use [5], while others do not [6]. Results from animal models suggest that NSAIDs and/or specific COX2 inhibitors may prevent $\mathrm{BC}[7,10]$.

COX2 expression is associated with carcinogenesis because it modulates apoptosis and thus disturbs organ homeostasis by decreasing the balance between proliferation and apoptosis [11]. In addition, COX2 may aid in later events leading to the malignant phenotype through its involvement in angiogenesis and invasiveness consistent with the prevailing notion that COX2 overexpression correlates with aggressive disease [12]. The proliferative activity of tumors has been studied extensively with different approaches. Among them, the monoclonal antibody Ki-67 represents an easy and reliable method of assessing cell proliferation [13]. The Ki-67 antibody reacts with a nuclear antigen $( \pm 350 \mathrm{kDa})$ that is present throughout the cell cycle of proliferating cells but is absent in quiescent cells (G0 phase) [14]. The aim of the present study was to access whether the administration of NSAIDs to patients with

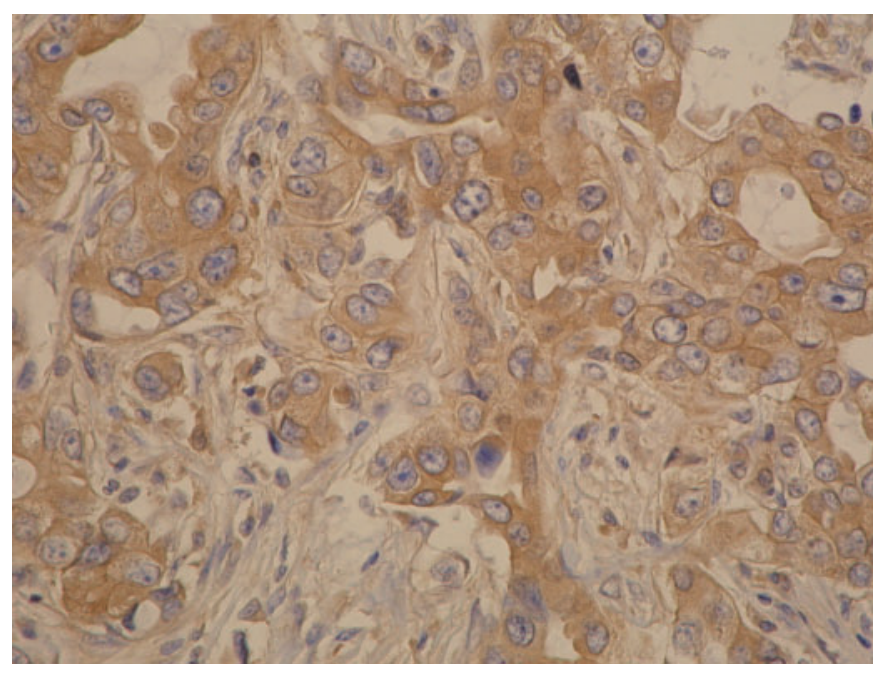

Fig. 1. Representative examples of COX2 immunostaining of breast cancer specimens: strong expression of COX2.

early $\mathrm{BC}$ prior to surgery modifies the proliferation index of the tumors. All tumors were COX2-positive before and after the treatment.

\section{Patients and Methods}

\section{Patients}

20 consecutive patients with histological evidence of primary BC provided by breast biopsies performed after abnormal breast mammography and/or ultrasound were screened for this study ( $>18$ years old, primary BC, no previous therapy for BC, no NSAID therapy, no distant metastasis). After the biopsy and prior to surgery, the patients were given $50 \mathrm{mg}$ of diclofenac (NSAID) 3 times daily (average recommended dose) for 15 days. Surgery was performed the day after the end of the course of medication. 13 patients gave their consent for the present study (mean age 61 years, range $42-84$ years; $38 \%$ of these patients were under the age of 50 ). The clinical and histological characteristics of the patients are summarized in table 1. COX2 and the proliferation index (Ki-67) were evaluated with the biopsies and tumors obtained after surgery.

\section{Histological Evaluation}

The sections from paraffin blocks were stained with hematoxylin and eosin for light microscopic study. The tumors were classified by histological type according to the criteria of the National Surgical Adjuvant Breast Project. The tumors were graded according to Scarff-Bloom-Richardson (SBR) [15]. The criteria for grading were nuclear features, the number of mitoses, and the presence or absence of tubular formation.

\section{Immunohistochemistry}

The specimens were deparaffinized, and antigen was retrieved using a microwave oven. The slides were then immersed in $0.6 \%$ hydrogen peroxide in methanol for 30 min to block endogenous peroxydase activity and in blocking solution for $5 \mathrm{~min}$ to block non-specific binding sites. Immunostaining was performed with a COX2-specific mouse anti-human monoclonal antibody (160112, Cayman Chemical Co., Ann Arbor, MI, USA). COX2 immunohistochemical staining was scored using the following scoring criteria: 0 , no staining; + , weak diffuse cytoplasmic staining (may contain stronger intensity in less than $10 \%$ of the cancer cells); ++, moderate to strong granular cytoplasmic staining in $10-90 \%$ of the cancer cells; +++, over $90 \%$ of the tumor cells stained with strong intensity. 
Immunohistochemical staining with the Ki-67 (proliferation marker) Ab-1 (clone MIB-1) mouse monoclonal antibody (dilution 1:50) (Labvision, Fremont, CA, USA) was performed with an antigen retrieval method we have described elsewhere [16]. The percentage of positive cells was counted in at least 500 tumor cells in both primary carcinoma and lymph-node metastases by 2 independent pathologists. Discrepancies were discussed and resolved. The results are expressed as mean \pm standard deviation (SD) (table 1). The comparison between the percentages of cells with Ki-67 activity was made using the Student's t-test (2-tailed, for equality of means).

\section{Results}

The tumor histology follows a usual repartition: $69 \%(n=9)$ ductal infiltrating carcinoma, $15 \%(\mathrm{n}=2)$ lobular infiltrating carcinoma, 7\% $(\mathrm{n}=1)$ lobular and ductal infiltrating carcinoma, $7 \%(\mathrm{n}=1)$ cribriform carcinoma. In ductal carcinoma, there were 6 SBR III tumors, 2 SBR II tumors, and 1 SBRI tumor. The majority of the tumors were estrogen receptorpositive - with 6 tumors being ER-positive / progesterone receptor(PR)-positive, and 4 being ER-positive/PR-negative) and only 3 were ER-negative/PR-negative. All of the tumors were COX2-positive before and after the treatment, but $38 \%$ $(\mathrm{n}=5)$ were only weakly positive.

The immunoreactivity of the Ki-67 antibody was distributed in 2 categories: 3 cases with mean proliferative index (5-10\% positive cells), and 10 cases with high proliferative index ( $>10 \%$ positive cells). In the breast biopsies, $23.9 \pm 13.5 \%$ $(6-49 \%)$ cells were $\mathrm{Ki}-67$-positive, while $23.2 \pm 12.5 \%$ (3.5-43\%) cells were Ki-67-positive in postoperative tumors (table 1). In 8 (61\%) cases, a decrease in Ki-67 activity of $1-8 \%$ was observed between the 2 cell populations, but this difference was not found to be significant (t-test for equality of means, $\mathrm{p}=0.99$ ).

\section{Discussion}

The optimal treatment for women with primary BC involves multiple methods including local radiotherapy and systemic therapy with hormonal agents, a combination of chemotherapies, or both. These treatments favorably alter the natural history of BC. Most women with primary BC have sufficient residual risk after regional therapy to benefit from systemic therapy, but for some that benefit is marginal [17].

Prostaglandin increases the expression and activation of aromatase [3] which is the enzyme that produces estrogen from androgens. Estrogen can increase breast tumor cell growth via activation of ER and its target genes. This is one mechanism by which $\mathrm{COX} 2$ could stimulate breast tumor growth. COX2 antagonists have been show to have antiangiogenic activity [8], and inhibition of $\mathrm{COX} 2$ can reverse resistance to apoptosis [18]. COX2 has also been implicated in growth factor production which stimulates angiogenesis [19]. Selective COX2 inhibitors have been developed on the hypothesis that, at comparable therapeutic efficacy, they would have a better safety and tolerability profile than conventional NSAIDs. Initially, we chose to use rofecoxib for this study, but this drug was withdrawn from the market in 2004 because of an association with a higher risk of cardiovascular events. Nevertheless, NSAIDs have been shown to inhibit breast and intestinal tumors in animal models. For this reason, we decided to use another NSAID. Diclofenac is a well-known NSAID with strong anti-COX2 activity and good tolerance. A treatment period of 15 days is very short, but we decided not to delay surgery. In our study, we compared the biological behavior of cells from primary breast tumors before and after treatment with diclofenac. The study of the Ki-67 index proliferation seems to us to be a good marker to evaluate a possible effect of this medication on BC. COX2 staining was observed in all tumors analyzed, but it was only weak for $30 \%(n=4)$. As for COX2 expression, no difference was observed between the 2 cell populations. We found that COX2 is expressed at intermediate or high levels in $70 \%$ of the breast tumors. In others studies, this rate was usually smaller, between 30 [20] and 43\% [21, 22].

This study confirms that COX2 is overexpressed in most breast tumors. Association of COX2 expression with clinicopathological parameters and ER and human epidermal receptor (HER) has not yet been extensively researched, and only high COX2 expression has so far been associated with reduced disease-free survival in ER-negative disease [23]. We found no significant difference between the 2 cell populations, only a trend towards a decrease. Certainly, the number of patients was too small to generate definitive conclusions, and we did not exclusively select patients with high COX2 expression in the tumors. Furthermore, the treatment duration was very short.

More in vivo studies with more patients are needed to determine if high COX2 expression could be an independent prognostic factor in BC. Also, in vitro studies are to be carried out to understand and compare the role of NSAIDs and selective COX2 in cancer prevention and treatment. After that, prospective randomized studies could be conducted into the prevention (alone) or treatment of BC. Indeed, preliminary results of such studies are very encouraging [24, 25].

\section{Conclusion}

COX2 is a potential target for the prevention and treatment of BC. We confirm that COX2 is overexpressed in BC. Prospective and randomized studies regarding the administration of NSAIDs or selective COX2 inhibitors in such patients are needed to verify the in vivo effect of such therapies and perhaps to develop new treatment strategies.

\section{Acknowledgments}

The study was supported by grants from Astra Zeneca SA, Brussels, Belgium and from Sanofi Aventis SA, Diegen, Belgium. 


\section{References}

1 Dubois RN, Abramson SB, Crofford L, Gupta RA, Simon LS, Van De Putte LB, Lipsky PE: Cyclooxygenase in biology and disease. FASEB J 1998;12: 1063-1073.

2 Williams CS, Mann M, Dubois RN: The role of cyclooxygenase in inflammation, cancer, and development. Oncogene 1999;18:7908-7916.

3 Zhao Y, Agarwal VR, Mendelson CR, Simpson ER: Estrogen biosynthesis proximal to a breast tumor is stimulated by PGE(2) via cyclic AMP, reading to activation of promoter II of the CYP 19 (aromatase) gene. Endocrinology 1996;137: $5739-5742$.

4 Liu CH, Chang SH, Narko K, Trifan OC, Wu MT, Smith E, Haudenschild C, Lane TF, Hla T: Overexpression of cyclooxygenase-2 is sufficient to induce tumorigenesis in transgenic mice. J Biol Chem 2001;267:18563-18569.

5 Harris RE, Namboodiri KK, Farrar WB: Non steroidal antiinflammatory drugs and breast cancer. Epidemiology 1996;7:203-205.

-6 Egan KM, Stamfer MJ, Giovanucci E, Rosner BA, Colditz GA: Prospective study of regular aspirin use and the risk of breast cancer. J Nat Cancer Inst 1996; 88:988-993.

7 Harris RE, Alshafie GA, Abou-Issa H, Seibert K: Chemoprevention of breast cancer in rats by celecoxib, a cyclooxygenase 2 inhibitor. Cancer Res 2000;60: 2101-2103.

8 Rozic JG, Chakraborty C, Lala PK: Cyclooxygenase inhibitors retard murine mammary tumor progression by reducing tumor cell migration, invasiveness and angiogenesis. Int J Cancer 2001;93: 497-506.

$\checkmark 9$ Kundu N, Fulton AM: Selective cyclooxygenase (COX)-1 or COX-2 inhibitors control metatstatic disease in a murine model of breast cancer. Cancer Res 2002; 62:2343-2346.

10 Harris RE, Beebe-Donk J, Alshafie GA: Reduction in the risk of human breast cancer by selective cyclooxygenase-2 inhibitors. BMC Cancer 2006;6: 27.

11 Dannenberg AJ, Altorki NK, Boyle JO, Dang C, Howe LR, Weksler BB, Subbaramaiah K: Cyclo-oxygenase 2: a pharmacological target for the prevention of cancer. Lancet Oncol 2001;2:544-551.

12 Ristimaki A, Sivula A, Lundin J, et al.: Prognostic significance of elevated cyclooxygenase- 1 and cyclooxygenase- 2 expression in breast cancer. Cancer Res 2002;62:632-635.

13 Rosai J (ed): Ackerman's Surgical Pathology, vol. 1, 8th ed. St Louis, Mosby, 1996.

14 Gerdes J, Lemke H, Baisch H: Cell cycle analysis of a cell proliferating associated human nuclear antigen defined by the monoclonal antibody Ki-67. J Immunol 1984;133:1710-1715.

15 Bloom H, Richardson W: Histological grading and prognosis in breast cancer. $\mathrm{Br}$ J Cancer 1957;11: 359-377.

16 Anaf V, El Nakadi I, Simon P, Englert Y, Peny MO, Fayt I, Noel JC: Sigmoid endometriosis and ovarian stimulation. Human Reprod 2000;15:790-794.

17 Schmoor C, Sauerbrei W, Bastert G, Bojar H, Schumacher M; The German Breast Cancer Study Group: Long-term prognosis of breast cancer patients with 10 or more positive lymph nodes treated with CMF. Eur J Cancer 2001;37: $1123-1131$.

18 Tsuji M, Dubois RN: Alterations in cellular adhesion and apoptosis in epithelial cells overexpressing prostaglandin endoperoxide-synthase-2. Cell 1995;83: 493-501.

19 Tsuji M, Kawano S, Tsuji S, Sawaoka H, Hori M, Dubois RN: Cyclooxygenase regulates angiogenesis induced by colon cancer cells. Cell 1998;93: 705-716.

20 Half E, Xi Ming T, Gwyn K, Aysegul S, Wathen K, Sinicrope FA: Cyclooxygenase-2 expression in human breast cancers and adjacent ductal carcinoma in situ. Cancer Res 2002;62:1676-1681.

-21 Sivula A, Talvensaari-Mattila A, Lundin J, Joensuu H, Haglund C, Ristimaki A, Turpeenniemi-Hujanen T: Association of cyclooxygenase-2 and matrix metalloproteinase-2 expression in human breast cancer. Breast Cancer Res Treat 2005; 89:215-220.

22 Singh B, Berrry JA, Shoher A, Lucci A: COX-2 induces IL-11 production in human breast cancer cells. J Surg Res 2006;131:267-275.

23 Witton CJ, Hawe SJK, Cooke TG, Barlett JMS: Cyclooxygenase 2 expression is associated with poor outcome in ER negative, but ot ER positive breast cancer. Histopathology2004:45:47-54.

24 Chow LWC, Toi M: Prospective pilot study of the preoperative use of celecoxib and FEC for the treatment of locally advanced breast cancer. Breast Cancer Res Treat 2002;76:S54.

25 Toi M, Chow LWC: Celecoxib antiaromatase neoadjuvant therapy for locally advanced breast cancer: preliminary results of a prospective randomized trial. Proc Am Soc Clin Oncol 2003;22:83. 